\title{
Do supremacismo á xenofobia: o idioma galego no pensamento castelán
} (séculos XV-XVII)

\author{
Alexandre Peres Vigo \\ Universidade da Coruña
}

Data de recepción: 20/07/2020 | Data de aceptación: 17/10/2020

\begin{abstract}
Resumo:
A percepción que os grupos humanos desenvolven sobre a lingua do Outro atópase ligada, en gran medida, con fenómenos como o favoritismo endogrupal e a caracterización estereotípica que acompaña o exogrupo, entre outros. No caso castelán, a consideración desfavorábel do galego coincide co xurdimento de posturas supremacistas e/ou xenófobas que afondan as súas raíces no castelanismo ideolóxico, plenamente desenvolvido ao longo do século XV. Nesta liña de estudo, o presente artigo analiza as causas do menosprezo social da lingua galega nos textos casteláns dos séculos XV-XVII, así como a súa relación coa galaicofobia no marco das relacións políticas e socioeconómicas entre Galiza e Castela.
\end{abstract}

\section{Palabras chave:}

Lingua galega; galaicofobia; supremacismo lingüístico; estereotipo antigalego; historia social da lingua galega.

\section{From supremacism to xenophobia: Galician language in Castilian thinking (15th-17th centuries)}

\begin{abstract}
:
The perception that human groups develop about the other's language is linked, to a great extent, to phenomena such as in-group favouritism and the stereotypical portrayal assigned to the out-group. In the Castilian case, the unfavourable view of Galician goes in sync with the emergence of supremacist and/or xenophobic stances deeply rooted in ideological Castilianism, fully developed during the 15th century. In this line of research, this paper analyses the causes of social disdain for the Galician language in Castilian texts of the 15th17 th centuries, as well as their ties with anti-Galician sentiment in the context of the political and socio-economic relationships between Galicia and Castile.
\end{abstract}

\section{Keywords:}

Galician language; anti-Galician sentiment; linguistic supremacism; anti-Galician stereotype; social history of the Galician language 


\section{Introdución}

Considerado como un dos elementos culturais máis representativos e definitorios dun grupo humano (Coupland, Giles \& Coupland 1991), a lingua e/ou as súas variedades non só ostentan unha posición preeminente e indisociábel na gran maioría de estereotipos étnicos e/ou nacionais senón que, en numerosas ocasións, este se erixe como o xenuíno categorizador grupal (Kristiansen 2003: 81), decisivo no xurdimento dun sentimento endogrupal como na creación do Outro (Wright 1998: 44):

Language is a group marker, an indicator of difference and ultimately both the medium and the message of the construction 'us' as opposed to 'them'. We categorise groups who cannot communicate with us as 'strangers'. Linguistic evidence from a number of languages shows how the definition of stranger comes from the idea of incomprehension and the impossibility of communication.

Historicamente, este tipo de consideracións grupais, en que a realidade lingüística adquire unha importancia crucial na conformación de grupos e da figura do Outro, resultaron comúns na literatura antiga. Neste sentido, cobran especial significación reflexións como as de Heródoto ou Xenofonte, onde a lingua se converte no auténtico e máis notábel delimitador étnico entre os helenos e aqueles exogrupos non-gregos, aos que se lles aplicaba o exónimo "bárbaros" (o Outro de fala non-helena), vocábulo posteriormente introducido no latín (Isaac 2004: 111-112). Este estreito vínculo, ben visíbel no pensamento e na literatura grecolatina, non só dota a lingua -atributo presente en practicamente todas as representacións heteroestereotípicas dun grupo étnico/nacional- dun forte vínculo co sentimento endogrupal e a imaxe de grupo, senón que, polo xeral, a consideración e o prestixio dunha lingua tamén se ven determinadas inversamente polo status social do grupo humano utente, así como polo estereotipo creado arredor deste.

Porén, cando o desequilibrio de poder entre sociedades resulta especialmente acusado (ben visíbel en contextos coloniais), o favoritismo endogrupal ou etnocentrismo da sociedade estereotipadora pode derivar, as máis das veces, nunha ideoloxía supremacista. Un fenómeno psicosocial que resulta explicábel a través da teoría da dominancia social, como unha praxe que busca lexitimar e xustificar o dominio dun grupo sobre outros (Jost \& Banaji 1994: 2). Deste xeito, a consideración propia do grupo dominante caracterízase pola atribución de elementos socialmente favorecedores, reservando para os exogrupos unha caracterización negativa e/ou demonizada de todos os seus atributos, especialmente sobre aqueles elementos máis definitorios como o idioma, dun xeito proporcional á rivalidade e/ou dominio sobre o exogrupo. 
No contexto europeo, este tipo de consideracións supremacistas, polas que un grupo humano e a súa lingua son concibidos como superiores ao resto de grupos, tamén resultan amplamente documentábeis desde a Antigüidade. No caso grego, o helenocentrismo e a propia concepción estereotípica dos "bárbaros" ( $\beta \alpha ́ \rho \beta \alpha \rho o 1)$, como aqueles individudos "whose language was incomprehensible and sounded like a repeated babbling «barbar» noise" (Ting-Toomey 1999: 157), denota por si mesma a existencia dun profundo desprezo cara ao Outro non-heleno, no seo dun pensamento marcadamente supremacista (Laforse 2013: 575) cuxo eixo vertebrador non era senón idioma. A diferenza do supremacismo étnico-lingüístico transmitido pola literatura grega, sen dúbida o pensamento romano -referencia inescusábel na análise diacrónica do pensamento imperialista- ofrece unha perspectiva supremacista máis influente en séculos posteriores, por canto estabelece unha consigna profusamente desenvolvida, baseada nunha "supremacist doctrine with claims to a civilizing mission and a universal and boundless empire” (Parchami 2009: 197).

Se ben que, como sinala Ehrensperger, "the Roman attitude replicated the Greek

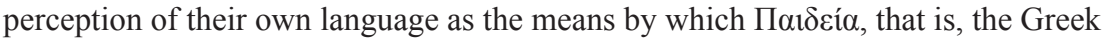
-civilized- way of life, was transmitted as that which distinguished Greeks from barbarians" (2013: 70), no caso romano, o latín foi concibido - a diferenza da Grecia clásica- como a lingua de Estado, ao menos no Occidente. Así, con independencia da súa penetración, o latín axiña se constituíu como "a symbolic expression of his citizenship" (idem), de modo que o Estado reafirmaba a súa superioridade a través do latín, tanto a través dun punto de vista legal como social, establecéndose como lingua das capas detentoras dun status socio-económico alto. Este fenómeno fascinaría os intelectuais europeos renacentistas (véxase o caso de Lorenzo Valla ou Antonio de Nebrija) e inspiraría as políticas de asimilación cultural e lingüística emprendidas polas potencias coloniais europeas, especialmente desde o século XVI, tal e como se observa nos casos castelán, portugués e inglés, entre outros.

Con todo, para alén do supremacismo lingüístico derivado, quer de posicións etnocéntricas (como as referidas para o mundo helénico), quer dun punto de vista nomeadamente político, como foi o caso do imperialismo romano, as relacións intergrupais ao abeiro de procesos migratorios tamén conformaron -e seguen a conforman- un recorrente e significativo axente no desenvolvemento de posturas e teses supremacistas e/ou xenófobas. Xurdidas ao abeiro da asimetría de poder entre grupos dominantes (receptores) e grupos emigrados, o status da lingua destes últimos adoita ser apenas a proxección do estereotipo que a sociedade estereotipadora (receptora) crea en función das diferentes relacións económicas, políticas e sociais entre ambas as dúas (Kang \& Rubin 2014: 242). 


\section{As orixes do castelán-centrismo e do supremacismo lingüístico no pensamento castelán renacentista: séculos XIII-XV}

Amplamente estudado polo mundo académico e intelectual, o reinado dos Reis Católicos caracterizouse, entre outros aspectos, polo desenvolvemento dun programa político de corte autoritario na coroa de Castela, a través dun profundo plan de reformas administrativas e lexislativas, así como a posta en práctica dun concepto uniformitario do Estado. Máis notorio no relixioso, no eido lingüístico o maior expoñente deste afán homoxeneizador é representado por Antonio de Nebrija, creador da primeira Gramática castellana, e o primeiro autor en teorizar acerca do valor político do castelán como unha ferramenta útil -mesmo indisociábel("compañera del imperio") na consolidación e expansión da monarquía castelá (véxase Binotti 2000).

Este binomio imperio-lingua, de calquera xeito, xa fora suxerido décadas atrás polo humanista romano Lorenzo Valla na súa obra Elegantiae Linguae Latinae (1441-49) ao reflexionar sobre a herdanza lingüística da Europa ${ }^{1}$ de fala romance, facéndoa auténtico símbolo -e legado- do poderío imperial acadado por Roma. En realidade, na xeografía ibérica a idea xa se atopaba ben asentada entre as capas letradas de Castela, como tamén naqueles eruditos peninsulares vinculados á monarquía castelá, caso do aragonés Gonzalo García de Santa María, quen en Las Vidas de los Santos Religiosos de Egipto (1486), xa en pleno reinado dos Reis Católicos, defendía o uso do castelán como lingua do incipiente imperio (ap. Mateo Palacios 2013: XLVII):

E porque el real imperio que hoy tenemos es castellano, e los muy excellentes rey y reyna, nuestros senyores, han escogido como por assiento e silla de todos sus reynos el reyno de Castilla, deliberé de poner la obra presente en lengua castellana, porque la fabla comúnmente, más que otras cosas, sigue al imperio. E quando los príncipes que reynan tienen muy esmerada e perfecta la fabla, los súbditos esso mismo la tienen. E quando son bárbaros e muy ajenos a la propiedad del fablar, por buena que sea la lengua de los vassallos e subjugados, por discurso de luengo tiempo se faze como la del imperio.

Porén, a ideoloxía lingüística que reflicten as palabras de García de Santa María, non representaba entón ningunha novidade nin a expresión dun imperialismo xurdido ao

1 "Nostra est Italia, nostra Gallia, nostra Hispania, Germania, Pannonia, Dalmatia, Illyricum, multaeque aliae nationes. Ibi namque romanum imperium est ubicumque romana lingua dominatur" (ap. Garber 2008: 43). 
abeiro da nova Monarquía Católica. Este tipo de teses supremacistas xa resultan visíbeis desde décadas atrás, coincidindo coa conversión definitiva do castelán en norma culta ou cortesá na coroa de Castela -e aínda iniciando a súa introdución na coroa catalán-aragonesa da man da dinastía castelá dos Trastámara, xa a comezos do século XV-, momento en que o castelán pasará ser asociado, política e socialmente, coa vangarda cultural e literaria, así como un idioma ligado indefectibelmente ao mundo cortesán. Para autores como Monsalvo Antón, a "orgullosa defensa de la identidad cultural de «el castellano» y de la identidad política de «lo castellano» (2011: 48) xa se albisca con plena clareza no reinado de Xoan II de Castela (14061454), así como noutros Trastámaras.

A fin de consolidar a súa autoridade nos reinos e señoríos da coroa de Castela, así como superar a imaxe dunha monarquía "born in bastardy and rooted in fratricide" (Deyermond 2009: 64), o discurso político dos Trastámara restou relevancia ao dereito por liñaxe, en detrimento dun discurso lexitimador arredor da propia monarquía, así como da vinculación co pasado de Castela. Para o alcanzar, o proxecto de consolidación rexio dos Trastámara alicerzouse, en gran medida, no relato propagandista que recuperaba o ideal neogoticista, a través do que se vindicaba unha pretendida superioridade da realeza castelá fronte a outras monarquías ibéricas e aínda europeas. Un castelanismo ideolóxico que, adoptado pola elite cultural castelá —e aínda pola peninsular non propiamente castelá-, impregnou, desde principios do século XV, gran parte da produción literaria en Castela, converténdose nun verdadeiro tópico literario entre os prehumanistas casteláns (véxase o caso paradigmático de Juan de Mena). Así se observa na obra Las Siete Edades del mundo (1418), onde o rabino burgalés Ha-Levi, bautizado posteriormente baixo o nome de Pablo de Santa María, presentaba a realeza castelá como "sucesora de las monarquías judía y romana", así como da "goda", da cal "no sólo es sucesora, sino también heredera legítima" (Deyermond 1985: 321).

Como sinala Monsalvo Antón, esta sorte de "nacionalismo" castelán recupera uns postulados ideolóxico-culturais, cuxa memoria acabaría "bien arraigada en los ambientes literarios" de Castela, concibida como un "reino potente, rico y tan orgulloso de su propia historia, cultura incluida" (2011:53), e onde destacan grandes apoloxistas como Pablo de Santa María, conselleiro de Henrique III e preceptor de Xoán II, Juan de Mena, cronista de Xoán II, Alfonso de Cartagena, secretario de Xoán II, ou Íñigo López de Mendoza, marqués de Santillana. No entanto, o punto de partida deste novo patriotismo castelán catrocentista, convenientemente promovido pola nova dinastía Trastámara, así como o supremacismo lingüístico que se impón na sociedade castelá, representa apenas un proceso gradual e constante, inspirado na recuperación propagandística dun ideal político castelanista que comezara a súa 
andaina no século XIII e que recuperaba, ao mesmo tempo, "el viejo ideal cortesano de Alfonso X de convertir el castellano en la gran lengua de la propia monarquía y la sociedad civil y política" (Monsalvo Antón 2011: 47).

Promovido desde a chancelaría real castelá, especialmente tras o triunfo de Fernando III fronte a monarquía galego-leonesa (1230) e fronte aos reinos andalusís (1236-1248), desde as esferas do poder rexio castelán, os intelectuais intimamente ligados á monarquía, tales como Juan de Soria — autor de Chronica latina regum Castellae- ou Rodrigo Ximénez de Rada — autor de De rebus Hispaniae-, convertéronse nos artífices dunha ideoloxía castelán-centrista que procurou a lexitimidade e a superioridade, non só política, de Castela e da súa monarquía no concerto peninsular, como herdeira dun pasado visigodo, mais tamén relixiosa, defendendo a primacía castelá de Toledo fronte a outras sés, nomeadamente perante Compostela (véxase Nogueira 2011: 170-183).

Esta ideoloxía sería plenamente oficializada por Afonso X de Castela (1252-1284), quen, para alén de recoller todo o legado historiográfico dos anteriores -entre outras fontes- e darlle forma na Estoria de España, desenvolvería unha aposta política marcadamente castelanista, promovendo a cultura e idioma vernáculo do reino de Castela e asumindo unha perspectiva político-cultural nomeadamente casteláncentrista. Así se observa ao longo da produción literaria afonsina, onde o propio rei deixa constancia da súa castelanidade, identificándose étnica e lingüisticamente en tal grupo ("nuestro lenguage de Castiella" e "dezimos en esta tierra [Castela]") (cfr. Niedereche 1985: 427), mentres que o monarca se exclúe doutros (exo) grupos, referíndose a eles en terceira persoa, tales como os galegos ("que chaman donezinha os galegos", di Afonso X nas Cantigas de Santa Maria; Ferreiro 2001: 257). Desde unha posición nitidamente castelá, o apoio ao castelán fronte a outras linguas e variedades lingüísticas dos territorios sometidos á autoridade rexia mesmo altamente prestixiadas como o galego-portugués-, será unha peza máis do proxecto político afonsino. Con esta, non só se procuraba unha uniformación da complexa realidade multiétnica que conformaba a coroa de Castela (casteláns, andalusís, galegos, vascos, astur-leoneses e xudeus), mais tamén a lexitimación do nacente dominio castelán, así como das aspiracións expansionistas da monarquía, presentándose como herdeira natural da monarquía hispano-visigoda (Fernández Gallardo 2016). Proxecto este, no que tamén cómpre situar o desenvolvemento dunha ampla literatura castelá arredor de auténticos mitos "nacionais" como o de Fernán González, os xuíces de Castela ou Mío Cid, servíndose "de un lenguaje político propio en la construcción de un poder regio legítimo" (Rodríguez 2003: 138). 


\section{O castelán-centrismo lingüístico e a lingua galega (séculos XIII-XV)}

A pesar do decidido pulo económico e político con que o proxecto afonsino dotou a escrita en castelán desde o século XIII como lingua rexia, -xa en 1250, Fernando III de Castela, se convertera no primeiro monarca en se dirixir aos composteláns en castelán (Mariño Paz 1998: 187)-, o prestixio social do galego(-portugués) -lingua lírica por excelencia no concerto ibérico do século XIII e na que o propio rei castelán levara a cabo o ambicioso proxecto das Cantigas de Santa María - semella ter conservado un status elevado na propia Castela da altura. Así o pon en relevo o propio uso literario da lingua galego(-portuguesa) por numerosos autores alleos aos reinos de Galiza e Portugal, tales como Pedro García Burgalés ou Alonso Fernández Cebollilla ou Martin Moxa entre outros, como tamén determinadas prácticas lingüísticas, tales como o uso deste idioma polas elites galegas, aínda a comezos do século XIV, cando estas se dirixían formal -e informalmente- aos reis casteláns. Un fenómeno que debía resultar por todo común, a xulgar pola descrición que don Juan Manuel recollía no seu Libro de los Estados, reparando no feito de que, nunha reunión persoal, Rodrigo de Padrón - arcebispo de Compostela entre os anos 1307 e 1316- fixera uso do seu "lenguage gallego" para se dirixir ao entón rei de Castela, Fernando IV.

Lonxe do que ocorrerá no século $\mathrm{XV}$, a anécdota lingüística incluída por don Juan Manuel -mordomo real do propio Fernando IV- non achegaba ningunha connotación negativa nin pexorativa sobre este feito, nin tampouco sobre a figura arcebispal galega, descrita dun xeito favorábel como amigo, buen omne, de muy buen entendimiento, de buena palabra. Sinalado xa por Monteagudo, este comportamento lingüístico non debeu resultar circunstancial nin anecdótico senón que, a través do epistolario arcebispal, esta praxe se mostra habitual e reiterativa, tal e como se observa na carta escrita en galego(-portugués) que o mesmo arcebispo compostelán enviaba ao toledano Gutierre Gómez, arcebispo de Toledo entre os anos 1310-1319, e persoa de confianza do propio Fernando IV (1994: 48-49).

2 “Acaeçió que un día [mi padre] ... díxome que avía un arçobispo en Santiago quel dixieran don Roy Padrón, que era mucho su amigo ....[e] porque el arçobispo avía ante convidado a don Johan ... fe comer con el. Et desque ovieron comido fincaron amos en la cámara apartados, departiendo muchas cosas; ca el arçobispo era muy buen omne et de muy buen entendimiento et de buena palabra. Et en manera de departimiento et de plazer, assí commo amigos que ellos eran, començógelo dezir en su lenguage gallego por esta manera:

- Don Johan, mío sennor et mío amigo, vien vos dezimos en verdat que nós beyemos muchas estorias et muchas corónicas, et sienpre fallamos en ellas que los fijos de los infantes fuera muy bien si fueran mejores. Et nunca fallamos que fueron muy buenos. Et aun los fijos de los infantes que agora son en Castiella, parésçenos que si maravilla non fuere non querrán fazer mintrosas las scripturas. Et plazernos ía mucho que vós, que sodes mucho nuestro amigo, que vos trabajedes que non fuesen en vos verdaderas..." (ap. Monteagudo 1994: 48-49). 
Con todo, a subida ao trono castelán de Henrique de Trastámara - a raíz do asasinato de Pedro I (1369) - e a definitiva promoción do castelán como parte do discurso hexemónico da realeza castelá, non sendo esta actitude "algo secundario o accesorio" (Monsalvo Antón 2011: 46), acabaron sendo determinantes na percepción e prestixio das linguas non-castelás no concerto da coroa. Para alén disto, no caso galego, a vocación netamente antitrastamarista das máis altas esferas do estamento nobiliario galego -aglutinados arredor da Casa de Castro-, quer apoiando o rei de Portugal quer apoiando un candidato da casa real inglesa (López Carreira 2005: 405-415), tivo, entre outras consecuencias, o envío de altos cargos casteláns ou castelanófonos a Galiza por parte dos monarcas casteláns; práctica que tamén se levaría a cabo en territorios "estraños” a Castela, como Asturias ou Biscaia (cfr. Monteagudo 1999: 127-135).

Esta nacente castelanización explica o desenvolvemento da escola galego-castelá mais tamén o abandono gradual do galego-portugués por parte de autores casteláns, tal como farían Garci Ferrandiz de Gerena, Álvarez de Villasandino (ca. 1345-ca. 1424) ou o arcediago de Toro. Por outra parte, a vitoria dos Trastámara supuxo a recuperación e desenvolvemento dun programa político-ideolóxico netamente castelán-centrista, especialmente durante o reinado de Xoán II (1406-1454), cando o monarca busque "sustentar ese proyecto cultural en la lengua castellana" (Monsalvo Antón 2011: 46), prestixiando este idioma en detrimento doutros, iniciándose, deste xeito, un menosprezo social daquelas linguas e variedades lingüísticas non-casteláns faladas no seo da coroa de Castela. A este respecto, non debe resultar casual a escolla do castelán na escrita literaria por autores galegos como Xoán Rodríguez de Padrón —estreitamente ligado á corte de Xoán II de Castela- á hora de redactar obras como El siervo libre de amor (1439).

Se cadra, un dos testemuños máis significativos do avance do castelán-centrismo lingüístico e do prestixio social do castelán como lingua cortesá se atope na sucinta consideración que o xudeu toledano e rabino de Maqueda, Mosé Arragel, facía constar na súa tradución da Biblia (1433), sinalando que tanto galegos, leoneses como sevillanos (andaluces) eran diferenciábeis dos casteláns polas súas "letras" e "modos de órganos", o que en opinión de Pensado (1999: 11) revelaba o preámbulo, xa na primeira metade do século XV, dunha limitada -mais incipiente- diglosia nas capas altas da sociedade galega (ap. Mondéjar 1991: 133):

Bervigracia en Castilla sean cognoscidos leoneses e sevillanos e gallegos. $\mathrm{E}$ aunque en parte quieran por via de descognoscimiento fablar vocablos e motes qualque [sic], tantos ende avera que ninguno destos cambiar non podra, por onde de nescesario cognoscidos son. 
Sen acusadas diverxencias de tipo relixioso ${ }^{3}$ ou fenotípico (cor da pel, trazos faciais etc.) respecto doutros grupos étnicos da xeografía ibérica, con independencia das diferentes focaxes con que se trate a súa filiación — especialmente no que ten a ver coas variedades portuguesas (mais tamén co continuum da área astur-leonesa)-, o certo é que, como lembraba Mosé Arragel, a lingua semella ter constituído o principal marcador de galeguidade no pensamento castelán catrocentista. Se callar, un dos testemuños que con maior clareza manifesten esta singularidade "nacional" con que Galiza era vista na Castela dos Trastámara, sexa a apreciación que Alfonso de Cartagena, bispo de Burgos e home de confianza de Xoán II de Castela, deitaba no seu discurso De Preeminentia (1434), con motivo do Concilio de Basilea, lembrando como o dominio castelán tamén se estendía sobre outras nacións con "diversos lenguajes", tales como "los gallegos e los viscainos" (ap. Monsalvo Antón 2011: 65):

El regno de Castilla sobrepuja a Inglaterra magnifiestamente, ca so el señorío de mi señor el Rey ay diversas nasciones e diversos lenguajes e diversas maneras (...) Ca los castellanos e los gallegos e los viscainos diversas naciones son, e usan de diversos lenguajes del todo.

Próximo aos territorios vascófonos, por mor da súa orixe burgalesa, así como coñecedor directo da realidade galega, en tanto que deán da sé compostelá desde 1415, para alén de estabelecer unha equivalencia entre "lenguajes" e "naciones", a apreciación de Alfonso de Cartagena "se enmarca en el contexto de exaltación de las excelencias patrias” castelás (Fernández Gallardo 2002: 414). Desta maneira, lonxe de motivacións humanísticas, a mención de Cartagena encádrase no proxecto político de engrandecer a monarquía castelá fronte o resto de estados peninsulares, mais tamén fronte á realeza inglesa, presentándoa como unha sorte de imperium cuxo dominio desbordaba o seu territorio natural, espallándose sobre outras nacións veciñas, caso de "los gallegos e los viscainos", do mesmo xeito que os monarcas ingleses exercían o seu dominio sobre galeses, irlandeses e aínda córnicos. Se ben Fernández Gallardo considera a apreciación, froito dunha "fina capacidad de observación lingüística" (2002: 414), malia non reflectir unha opinión expresamente contraria ás linguas galega e éuscara, a reflexión de Cartagena xira arredor dun castelanismo político que promulga, en calquera caso, a supremacía de Castela no terreo político, social e cultural dentro -e fóra- do ámbito ibérico, ben patente ao longo da súa apoloxética (ap. Monsalvo Antón 2011: 64-65):

Mi señor el rey de Castilla, considerada la sangre de sus antecesores, es muy noble. Ca no solamente desciende de los reyes de los godos e de las casas de Castilla e de León mas aun de linage de todos los reyes de España [...]entre los

3 Excluíndo por tanto os diferentes pobos peninsulares/ibéricos islamizados desde o século VIII. 
quales el principal e primero e mayor es el rey de Castilla e de León, nunca fueron subjetos al emperador [...] E así el regno de Castilla es de los más antiguos regnos del mundo.

A respecto do factor lingüístico como elemento delimitador ou identificador da personalidade étnica ou nacional de galegos e vascos ("biscaíños"), non cabe dúbida de que, en ambos os casos, este exerceu unha decisiva influencia na concepción alóxena duns e outros na sociedade castelá catrocentista. Así se colixe, entre outros, do reparto utilizado durante o século XV pola Universidade de Salamanca para aglutinar o seu alumnado en catro nacións, criterio estabelecido desde a primeira constitución de $1422^{4}$, de modo que, entre elas, se atopaba unha nación propiamente astur-leonesa e outra galego-portuguesa, esta última estendida sobre as dioceses de Portugal e Galiza, sumando ademais a diocese de Astorga, sé historicamente vinculada á Gallaecia e en cuxa parte occidental se situaba unha amplo territorio de fala galega. Esta consideración debía estar ben arraigada na mentalidade castelá, a xulgar por referencias "nacionais" como as incluídas nas Constituciones del colegio del Arzobispo de Toledo en Salamanca, en que se limitaba o número de "gallegos" e "vizcaínos", así como persoas de "otros reinos extráñeos" (ap. Sala Balust [ed.] 1962: I, 103), dun xeito similar ao que en 1535 se observan nas exclusións do colexio maior de Cuenca, ao establecer que "sus escolares deben ser de nación castellana, y que de Vizcaya y Galicia y de los reinos extraños -Francia, Aragón, Navarra y Portugal- se puede admitir solamente uno" (ap. Lario Ramíez 2004: 142).

\section{O galego fronte ao supremacismo lingüístico castelán: do lenguage gallego á barbara lengua}

Se na primeira metade do século XV se observa un castelán-centrismo lingüístico, derivado, en boa medida, dun castelán-centrismo político, amplamente desenvolvido durante o reinado de Afonso X (1252-1284), será na segunda metade desta mesma centuria cando en Castela se comece "a desprestigiar las lenguas hispánicas noroccidentales con el fin de prestigiar la lengua centro-meridional, esencialmente castellana" (Pensado 1985: 28). Se cadra, o máis significativo exemplo deste supremacismo lingüístico emerxente se atope no prólogo de Las Vidas de los

4 Cfr. "Las referidas naciones eran cuatro, a cada una de las cuales, según la constitución primera de 1422, correspondían dos consiliarios. En esta misma constitución primera se precisan las diócesis y reinos que entran en cada nación. El reino de León se distribuye en dos naciones: Galicia con Astorga y Portugal una, y el resto del reino otra. Castilla la Nueva con Andalucía formaba la tercera nación, y Castilla la Vieja con Navarra, Aragón y demás reinos extraños la cuarta. Plasencia, como perteneciente a la provincia eclesiástica de Toledo, va incluida en Castilla la Nueva y por tanto en el tercer grupo" (Beltrán de Heredia 1966: I, 93). 
Santos Religiosos de Egipto (ca. 1486-1491), onde Gonzalo García de Santa María encomiaba o castelán, o que considera como "lenguaje esmerado", fronte o resto de linguas faladas na coroa de Castela (ap. Mateo Palacios 2013: XLVII):

E por tanto se fallan en las antiguas corónicas e partidas de Espanya e Castilla, e otros libros, algunos tan antiguos vocablos, que de vejes han perdido su lustre e cabida. Hay allende esso en la misma Castilla, como son diuversos reynos en un ayuntados, algunas tan grosseras e ásperas lenguas, como es Galizia, Vizcaya, Asturias e Tierra de Campos, que ni aquellas ni lo muy andaluz es houido por lenguaje esmerado. E a lo vno de muy gruesso e rudo se pierde e lo otro de muy morisco.

Con todo, os encargados deste louvor social do idioma castelán, non serán, en van, aqueles mesmos intelectuais áulicos - caso do propio García de Santa María- que enxalcen, por igual, a propia Castela e a súa monarquía, utilizando o termo "imperio castellano" para, se callar, reflectir o expansionismo castelán no norte de África. Desde este punto de vista, a promoción do castelán conformaba unha xenuína ferramenta de asimilación étnica e política, necesaria - como defendía Nebrija- para sustentar un proxecto imperialista ao que aspiraban os propios monarcas castelánaragoneses, tal e como se deduce das palabras que Nebrija atribuía a Hernando de Talavera, entón bispo de Ávila (ap. Pérez Priego 1992: II, 768):

El mui reverendo padre Obispo de Ávila me arrebató [di Nebrija] la respuesta; e, respondiendo por mí, dixo que después que vuestra Alteza metiesse debaxo de su iugo muchos pueblos bárbaros e naciones de peregrinas lenguas, e con el vencimiento aquéllos ternian necessidad de recebir las leies quel vencedor pone al vencido, e con ellas nuestra lengua, entonces, por esta mi Arte, podrían venir en el conocimiento della.

Á relevancia política da lingua aínda se referiría, apenas unhas décadas máis tarde, o polígrafo florentino, Niccolò Machiavelli, en Il Principe ou De Principatibus (Florencia, 1532), identificando a diverxencia lingüística entre a metrópole e a periferia como un factor que dificultaba o dominio efectivo dun territorio a cargo dun monarca foráneo (Machiavelli 2009: 111):

Dico pertanto, che questi Stati, i qualiu acquistandosi si aggiungono a uno Stato antico di quello che gli acquista, o sono della medesima provincia e della medesima lingua, o non sono. Quando siano, è facilità grande a tenergli, [...] Ma quando si acquistano stati in una provincia disforme di lingua, di costumi e di ordini, qui sono le difficultà, e qui bisogna avere gran fortuna e grande industria a tenerli.

Será neste contexto renacentista de exaltación castelanista cando diversos intelectuais, moi vinculados á universidade de Salamanca, a máis notábel entón da monar- 
quía castelá, como Juan de Enzina, comecen a introducir figuras marxinalizantes non castelanófonas cun claro sentido cómico e xocoso. Sen dúbida, deles a máis coñecida será a figura do pastor "sayagués" — habitante da comarca leonesa Sayago-, concibido como a perfecta "antítesis del cortesano que habla según la norma toledana" (Lezcano 1993: 744), xurdindo, deste xeito, o "sayagués" como unha "jerga literaria artificial a finales del siglo XV, para producir la hilaridad de los oyentes [casteláns]" (Gutiérrez Cuadrado \& Pascual 1995: 348).

No entanto, como ten sinalado Buezo (1994: 420), a figura marxinalizante do chamado "sayagués" ou pastor semella xestarse nun contexto cronolóxico onde o idioma galego - xunto outras linguas peninsulares como o éuscaro ou o asturleonés - xa resultaba deostado pola intelectualidade, e aínda, se callar, no conxunto da sociedade castelá. Este desprestixio resulta patente, entre outros, nas palabras con que "anónimo traductor castellano del latinista italiano Guarino Veronese (De linguae latinae differetiis, traducida entre 1465-1480)" se refería "al habla de Babia como prototipo de rusticidad, impropia de buenos modales cortesanos" (Viejo Fernández 2016: 81), constituíndo para Viejo Fernández unha das primeiras valoracións despectivas sobre o idioma astur-leonés (González Ollé 1999; ap. Viejo Fernández 2016: 81):

Un señor en Castilla, si un fijo le fuese nasçido e criado en Viscaya o en Bauia, antes que le llevasen a la corte del rey, le daría uno que le enseñase a bien e conplidamente hablar.

A mesma necesidade de adquirir unha aceptábel competencia lingüística en castelán aínda sería manifestada por Nebrija na súa Gramática castellana (Salamanca, 1492), facendo da lingua non só un instrumento ao servizo da cruzada cristiá contra os granadinos ("no solamente los enemigos de nuestra fe, que tienen la necesidad de saber el lenguaje castellano"), máis tamén sobre "los vizcaínos, navarros, franceses, italianos y todos los otros que tienen algún trato y conversación en España" (ap. Binotti 2000: 262). Porén, no caso biscaíño, mesmo é posíbel atopar referencias desfavorecedoras sobre éuscaro na literatura ibérica desde mediados do século XVI, tal e como se observa na poesía 101 do poeta e cabaleiro valenciano Ausiàs March (ca. 1400-1459), onde o biscaíño ("viscahí") é concibido como paradigma de lingua incomprensíbel (ap. Cabré 2008: 530):

Lo viscahí qui $\cdot$ s troba'n Alemanya, paralitich, que no pot senyalar, si és malalt, remey no li pot dar metge del món, si donchs no és d'Espanya, qui del seu mal haurà més conexença $\mathrm{y}$ entendrà molt millor sa qualitat. 
A pesar de que a comunicación entre un xermanófono está lonxe de se mostrar, $a$ priori, máis fluída cun catalanófono - como era o propio March- que cun euscaldún, a figura do viscahí como utente dun idioma non-romance e carente, xa que logo, dunha filiación lingüística con outros idiomas peninsulares denota a existencia dun estereotipo negativo sobre o éuscaro no contexto centropeninsular -inclusive levantino - na primeira metade do século XV. Se cabe, máis sorprendente resulta a adaptación metalingüística que deste mesmo sermón se levaría a cabo en Castela por Pedro Marín, quen ao procurar un exemplo de inintelixibilidade lingüística decidiría prescindir da figura do biscaíno - a cal non debía ignorar- e adaptar o tema ao mundo estereotípico netamente castelán, trocando o "viscahí qui·s troba·n Alemanya" polo "el gallego estando en Austria” (ap. Cátedra 1990: 143):

E como el honbre aquí es dicho animal asociabile per naturam por respecto de los brutos, así el dicho Philósopho lo llama animal político e ceuil en respecto de los a él conformes en natura specífica con que ha de conveuir. E por quanto esta conueniencia tiene a los octros honbres e en sus neccessidades á vsar dellos e de sus cosas, es neccessario que declare su concepto e deseo a los convinientes. E esta declaración á de seer por señales comunes a todos, que si el que á neccessario la cosa notificasse su desseo por señal ho significación non común, ante ygnota, a aquél a quien tempta notificar e significar su concepto, su deseo sienpre estaría ascondido, e, así, en su neccessidade non sería proueído. Como si el gallego estando en Austria demandasse pan sin octra significaçión senon de pallabra al alamán que non entendiesse su lengua. E, por ende, Dios e la naturaleza dieron al honbre instrumentos naturales: labios, dientes, lengua, arterias, pulmones, según se toma del Philósopho.

A este respecto, cómpre reparar en que esta mudanza identitaria tamén virá da man dunha adaptación igualmente estereotípica, de xeito que se a necesidade do biscaíno xurdía no orixinal valenciano dunha parálise, a do "gallego", seguindo a concepción castelá deste pobo, non podía ser outra que a da fame, consideración que xa se observa na paremia castelá "Ayunas gallego a pesar de o demo" (ap. Bizarri 1995: 79), recollida polo Marqués de Santillana por volta de 1454.

Sen conter a priori ningún tipo de prexuízo lingüístico ou xuízo minusvalorativo - a diferenza da consideración supremacista coa que García de Santa María se referir ao galego como unha das "grosseras e ásperas lenguas" non castelás-, non cabe dúbida de que as respectivas escollas do "gallego" - como do "viscahí"non resultan arbitrarias. A transformación que Pedro Marín realiza do biscaíño -figura ben coñecida en Castela-, converténdoo en galego, non só revela unha consideración alóxena deste idioma -en termos similares como para o valenciano Ausiàs March era o éuscaro--, mais tamén a existencia latente dunha imaxe negativa destes idiomas, como linguas confusas ou inintelixíbeis, ligado 
a un estereotipo desfavorecedor que, polas mesmas datas, comezaba a revelar os seus inicios. Exemplo do arraigo que esta consideración asociada ao galego debía posuír no pensamento castelán, atópase na reflexión que en 1534 realizaba Francisco Delicado na súa versión do Primaleón. É nesta obra, onde Delicado, teorizando arredor da conveniencia de unificar criterios ortográficos, a fin de evitar a diversificación lingüística e a posterior incomprensión entre falantes, o escritor inclúa unha referencia aos galegos, referíndose a eles como exemplo paradigmático de comunicación confusa (1534: fol. CLXXVIv [bis]):

Como seria escrevir con dos esses lo que se ha de escrevir con esta letra, $\mathrm{x}$, o donde ua una, 1 , poner dos, 11 , o donde ua un "ca" poner "cha" o donde una "n" con tilde "ñ" poner "gn" donde ua un "ça" poner un "za" deguissa que todos çaçarabaçeavamos [sic] que pareciemos gallegos que no mos [sic] entendíemos.

De calquera xeito, esta mesma idea, xa aludida por Pedro Marín na anterior centuria, non representa unha idea persoal nin unha reflexión cinguida ao eido académico nin intelectual, senón que esta semella ter gozado de gran popularidade no conxunto da sociedade castelá renacentista. Así o demostra a existencia da paremia popular "O somos gallegos: o / no nos entendemos", recompilada a mediados do século XVI por Pedro Vallés no seu Libro de refranes (1549), e aínda recollida, entre outros, por Hernán Núñez de Toledo nos seus Refranes o Proverbios en Romance (1555) baixo a forma "Somos Gallegos, y no nos entendemos" (1555: fol. 122r). Mesmo a súa existencia previa ao ano 1492, ano da expulsión dos xudeus das coroas de Aragón e Castela, parece deducirse, como sinala Chacón Calvar, da súa presenza no refraneiro sefardí baixo as formas "somos gallegos, y no mos entendemos" e "favlamos gallego y no mos comprendemos" (ap. Chacón Calvar 2015).

Embora ter sido interpretado tradicionalmente como unha alusión ao mal relacionamento entre galegos (Esteban 2003: 190), unha tese cuxo iniciador puido ser o sacerdote zamorano Juan de Ocampo ao tentar explicar este "[r]efran tã usado en Castilla" a través dunha apócrifa anécdota contida en Descendencia de los Paços de Proben (1587), sería, no entanto, o castelán Sebastián Horozco quen no seu Teatro universal de proverbios (ca. 1570-1580) xa ofreza unha interpretatio fundamentada na confusión e a inintelixibilidade (Horozco 2005: 474):

Adonde quiera que son diversas gentes y trages no se escusa confusión como fue en ia fundación de Babel y sus lenguajes. 


\begin{abstract}
Todos andamos tan ciegos
que ninguna cosa vemos

clérigos, frayles y legos.

Assi que somos gallegos

o en fin no nos entendemos.
\end{abstract}

O caso galego, con todo, non resultou excepcional dentro do refraneiro castelán/ español. Así o proba a convivencia desta con outras expresións similares que carecen de calquera filiación ou asociación co reino de Galiza ou as súas xentes, e que reforzan a tese manifestada por Sebastián Horozco. Entre elas atópanse algunhas como as recompiladas por Gonzalo Korreas no seu Vokabulario de rrefranes i frases proverbiales (1627), tales como "Somos griegos, i no nos entendemos" e "estan komo unos griegos tienen mui grande gregería" (1627: 368), coas cales se facía alusión a "kuando aí bulla i gríta", reiterando, deste xeito, o sentido de lingua incomprensíbel, sempre desde unha perspectiva castelanófona obvia. Unha interpretación colixíbel, por igual, na variábel deste refrán castelán: “todos somos negros y no nos entendemos", expresión, esta última, que xa fora utilizada uns anos antes polo xesuíta calabrés Gerónimo Pallas na súa obra Missión a las Indias (1619), para referirse a un "lenguage [...] mesclado y corrompido", o cal "no avrá calepino que lo interprete" (Pallas 2006: 164).

De acordo con autores como Obeng e Adeghija, manifestacións como estas, a través das que un grupo cualifica a lingua do Outro como "confusa" ou "incomprensíbel", representa historicamente unha das praxes sociais máis comúns de desprezo do Outro, quer identificado como un grupo rival ou inimigo político, quer como un grupo humano que é tratado como inferior, o que, en última instancia, representa unha verdadeira expresión de etnocentrismo e supremacismo, corrente en grupos que se senten superiores a outros (1999: 361):

The ethnic consciousness had thus brought with it a reawakening of resentful feelings; some members of some ethnic groups thought of themselves as superior to all other peoples and hence looked down on languages other than their own and on the people who speak such languages.

Este tipo de crenzas ou consideracións sociais — de teor universal— resultou común no contexto ibérico moderno, e aínda no contemporáneo, tal e como poñen de manifesto as numerosas expresións metalingüísticas, aínda hoxe vixentes, con que se procura o desprestixio do exogrupo. Así, aínda resulta común a locución castelá "hablar en cristiano" como sinónimo de falar unha lingua comprensíbel, procurando deste xeito o enxalzamento do endogrupo, mentres en contraposición se atoparía o termo "algarabía" con que se denomina tradicionalmente a "lingua árabe", sinónimo 
-desde a perspectiva cristiá peninsular- dunha "lengua atropellada o ininteligible", "enredo, maraña" ou "gritería confuso de varias personas que hablan a un tiempo" (Real Academia Española 1770: s.v. algarabia). Esta expresión aínda tería o mesmo valor no castelán que "hablar en chino", ou "speaking Greek" no inglés, e xa no castelán do século XVI se debía atopar ligado á lingua galega baixo a paremia "o somos gallegos o no nos entendemos".

Porén, o rexeitamento de Delicado sobre a fonética galega non será a única alusión pexorativa con que o autor cincocentista manifeste certos prexuízos negativos cara ao idioma galego ou o xeito de falar dos galegos. Similar tratamento se atopa no propio Primaleón cando, ao tratar as referencias lingüísticas daqueles cortesáns que aspirasen empregar un "mas elegante vocablo", Delicado recomendaba atender ao falante nativo toledano -por "rudo" que este for-, evitando a forma de falar tanto do galego - por "letrado" que este for- como do "polido cordoves", acaso debido ao "abuso" de arabismos 5 neste último aínda cando o castelán levaba case tres séculos de presenza no reino andaluz (1534: ff. CLXXVIv [bis]- CLXXVIIr):

deste otro libro de Primaleõ digo q deprendi la Orthografia de Castilla la alta porque soy de Castilla la baxa y junto ami tierra dizen zarro y en la vuestra dizen jarro y a ca dezimos cueros y alla vosotros odres por ser mas elegante vocablo, demanera [sic] que mas presto se deve escuchar el hablar de un Rudo Toledano en su çabio razonar que no al Gallego letrado, ní al polido Cordoves $\&$ aqui dare yo mi alcaldada.

A través desta reflexión, o xuízo de Delicado revela a existencia dunha concepción lingüística graduada, cuxo fundamento repousaba nunha escala de valores étnicolingüísticos cuxa cúspide estaba dominada polos casteláns. En concreto, Delicado sitúa no cume social e lingüística os "de Castilla la alta" ou setentrional, aos que comunmente se lles supoñía un uso de voces máis “elegantes”, mesmo a respecto dos seus compatriotas meridionais, os casteláns de "Castilla la baxa" (grosso modo, o entón reino de Toledo). Con todo, a linguaxe destes últimos, emanada da capacidade dos seus habitantes para se adecuaren aos casteláns do norte, marcaba unha clara diferenciación co resto de pobos peninsulares non-casteláns que, en opinión de Delicado, empregaban as súas "linguas bárbaras" sen adoptar o uso do castelán, a diferenza do sucedido nos territorios casteláns alén do Sistema Central, o territorio que Delicado denomina “Castilla la baxa” (1534: fol. CLXXVIIr):

5 Cfr. "ni lo muy andaluz es avido por lenguaje esmerado, ca lo uno de muy gruesso e rudo se pierda, y, lo otro de muy morisco en muchos vocablos, apenas entre los mismos castellanos se entiende" (ap. Mateo Palacios 2013: XLVII-XLVIII). 


\begin{abstract}
Dime un poco? Porque note allegas al latin quando dizes hazer o hijo \& hurtar y hidalgo? Esta letra h no se escrive en latín para dezir facio, filio, furto, fidalgo. Si dizes que esta bien porque la usanza es mas que la ley callare. Mas ni los Gallegos, ni Vizcaynos, ni Navarros, ni Aragoneses, ni Portogeses, ni Catalanes no conforman sus barbaras lenguas con los Castellanos como lo fazen los de Castilla la baxa.
\end{abstract}

Para alén da propia gradación social estabelecida por Francisco Delicado, das consideracións lingüísticas expresadas polo intelectual e da súa referencia ás linguas peninsulares non-castelás como "bárbaras", cabe extraer non só a inexistencia, na altura, dunha identidade común hispánica, de modo que aquelas "provincias que son fuera de Castilla la alta", tales como o reino de Galiza, Asturias, Navarra, Biscaia, e os territorios catalán-aragoneses, eran tratados de "bárbaros" e/ou estranxeiros, máis tamén a excepcionalidade andaluza. Neste punto, Delicado sitúa a Andalucía como un enclave ao que non se debe aplicar o epíteto de "bárbaro", pois debido á súa filiación lingüística castelá, esta ostentaría unha posición privilexiada na escala étnica de valores sociais tras os habitantes de "Castilla la baxa" ao non pertencer ao grupo de "provincias bárbaras": "es q̃ todas las otras provincias que son fuera de Castilla la alta son barbaros a los castellanos salvo los de la fermosa Andaluzia" (Delicado 1534: fol. CLXXVIIr):

Este vocábulo, bárbaro, durante o século XVI debeu gozar de plena normalidade na linguaxe e no imaxino colectivo castelán para cualificar os idiomas non casteláns, tal e como mostra o seu uso a cargo do eclesiástico castelán Jerónimo Román y Zamora, en Repúblicas del mundo (Salamanca, 1595) ao se referir á "barbara lengua delos gallegos" (1595: III, fol.70r). Un criterio que, en calquera caso, non pode ser considerado senón a proxección dunha imaxe que vía nos galegos -e asturianos- a perfecta antítese dos civilizados casteláns, de acordo coa opinión que defendía o propio Román y Zamora nunha sorte de biodeterminismo xeográfico (Peres Vigo 2019: 75-77).

Se cadra, un dos xuízos minusvalorativos cincocentistas máis nítidos sobre o idioma galego se atope, paradoxalmente, na pluma dun dos "grandes apologistas de Galicia” (Pensado 1985: 24), o granadino Bartholomé Sagrario de Molina, quen na súa Descripcion del Reyno de Galizia (1550), consideraba a maior presenza do castelán en Compostela como unha virtude salientábel da metrópole galega (1551: fol. XXXVIIIr):

por la ciudad de compostela: do esta el glorioso apostol que esto solo bastaua para hablar de este pueblo: el cual es poblado de gente noble y rica: parece estar fundada enlo bueno de castilla: y avn la lengua gallega no permanesce aqui mucho. 
Máis apoloxista dos monumentos e liñaxes de Galiza que da súa lingua e moradores, "porque de su lengua y de las gentes que la hablaban, nada bueno dijo" (Pensado 1985: 24), a opinión de Molina pon de manifesto a existencia, na altura, dun acusado supremacismo lingüístico a través do que celebraba a menor presenza de lingua galega en Compostela —onde abundaba a presenza de eclesiásticos chegados de fóra de Galiza-, o que para Pensado viña a significar que Santiago era, para Molina, "una ciudad tan buena que hasta parece que es castellana, no gallega" (1985: 24).

Para autores como Bourhis e Maass, este tipo de gradacións e favoritismos endogrupais, así como os xuízos semellantes emanados das plumas de Delicado, Nebrija, Santa María ou Román y Zamora, parten do feito de os endogrupos seren máis proclives a xulgar positivamente os exogrupos cando estes comparten elementos (culturais, relixiosos, lingüísticos etc.) que a aqueloutros grupos que se presentan máis diverxentes, especialmente cando estes carecen dunha posición social vantaxosa (2005: II, 1590v):

in a large number os language stereotype studies conducte else-where in the world which show that the in-group accent or language variety is evaluated more favorably on solidarity dimension, while the out-group speech variety is upgraded on status trait if the out-group accent of language is used by a ruling elite or a dominant majority.

Embora estar definida por un forte favoritismo endogrupal que desde mediados do século XV superaría posicións etnocéntricas para, posteriormente, avanzar cara a un acusado supremacismo lingüístico -tamén político-, a especial negatividade que envolveu o idioma galego desde mediados do século XV, non pode ser considerada, en calquera caso, como un fenómeno particular e/ou radicado apenas no eido lingüístico. Como subliñan Kang \& Rubin, este tipo de prexuízos lingüísticos, ligados a estereotipos grupais marcados pola negatividade social están determinados por un mecanismo que a psicoloxía social vén en denominar "reserve linguistic stereotyping" (RLS) ou estereotipación lingüística inversa, pola que a consideración social do idioma se estabelece mediante a consideración social do grupo (2014: 242):

RLS [reserve linguistic stereotyping] suggests that listeners ascribe stereotyped characteristics to speech (i.e., listeners hear nonstandard accent where none maybe present, for example) based on information supplied about the speaker's social identity even before hearing the speech.

Desde este punto de vista, o especial desprezo -recórdese a expresión "somos gallegos y no nos entendemos"- que o pensamento castelán renacentista atribuíu ao idioma galego como un idioma inintelixíbel, groseiro, áspero e bárbaro, non sería 
senón o reflexo da negatividade social que Galiza e os seus habitantes xa acusaban no imaxinario colectivo en Castela catrocentista. Un estereotipo desvirtuado que xa se manifestaba en paremias populares recollidas na segunda metade de século, como "Mete gallego en tu pajar, y faser se te ha heredero" (García de Castro 2006: 195), ou "Ayunas gallego a pesar de o demo" (ap. Bizarri 1995: 79). A estes ditos e refráns aínda cabe engadir referencias propias do mundo erudito castelán, tales como a alusión de Alfonso de Palencia á "perfidia dos galegos" (1999: II, 229) ou a "ferocidade" que Juan de Mena atribuía ás xentes do reino de Galiza no seu poema alegórico El Laberinto de Fortuna (ca. 1444), tamén coñecido como Las trezientas (Mena 1501: fol. 15 [s.p.]):
Ui las p[ro]uincias de españa y poniente
La de tarragona y la celtiberia
La menor cartago q̃ fue la de esperia
Con los rincones de todo ocidente
Mostro se vãdalia la bien pareciente
y toda la tierra dela lusitania
La braua Galizia con la tagitania,
Donde se cria feroce la gente.

\section{De lingua bárbara a lingua de aguadores y lacayos}

Se até a primeira metade do século XVI a figura dos galegos estivo ligada, principalmente, á imaxe da Galiza pobre e rústica, no marco das relacións periferiametrópole, ao longo da segunda metade da centuria o "gallego" pasará a ser concibido no pensamento/ideario castelán como un individuo indefectibelmente ligado á condición inmigrante. Neste cambio de paradigma estereotípico resultou determinante tanto a estabilización da corte castelá en Madrid en 1561, convertida en foco de atracción migratoria, como o período de chuvias, pragas e fames que desde os anos 60 do século XVI azoutou o agro galego (véxase Martínez Rodríguez 1998: 452), feito que explica o contexto responsábel dun movemento migratorio constante que expulsou milleiros de campesiños galegos á corte madrileña e outras urbes e vilas castelás.

Este fluxo migratorio, constante desde os anos 70/80 do século XVI, así como as precarias condicións dos inmigrantes galegos, explica como ao longo da Idade Moderna "la servidumbre madrileña procedía mayoritariamente de Galicia, dibujada por los poetas de la Corte como una tierra pobre y mísera" (Herrero García 1966: 202). Esta novo contexto marcará as relacións galego-castelás de xeito que, como 
concluía Pensado, na sociedade castelá da altura -e aínda en séculos posteriores“el pastor ya no es lo más bajo de la escala social, hay otra clase social más baja en las ciudades peninsulares: la de los gallegos emigrados (1985: 286).

Como consecuencia desta situación, obsérvase o avance dunha hostilidade particular cara á lingua galega que afonda no castelán-centrismo e mesmo o supremacismo lingüístico -plenamente visíbel no xuízo do licenciado Molina- dando paso a referencias propiamente antigalegas. Dentro desta mudanza conceptual, sen dúbida se sitúa o xuízo de Bartholomé de Villalba y Estaña, cando en El Pelegrino Curioso (1577) o escritor valenciano se refira cunha "ironía tan descarada" (Pensado 1985: 30) á "la extrañeza de la tierra de Galicia, la abundancia de frutales campestres y con buenas frutas, sus modos tan exquisitos en todo, sus vocablos graciosos" (1886 [1577]: I, 373-374). Vocábulos, aparentemente "graciosos", aos que Villalba y Estaña se referirá en termos pexorativos na súa despedida poética a Galiza, onde o valenciano incluía boa parte do repertorio de tópicos antigalegos da altura, tales como a sucidade ("ni aún olerte"), a fealdade ("no es por verte") e a repugnancia polo idioma galego ("oirte no querría"):

Galicia, á Dios te queda, que te juro que si al Patron de España no tuvieras metido en Compostela, á buen seguro que jamas en tus términos me vieras. Podria ser que en tiempo, que es futuro, me vuelva á pasear por tus riberas, mas yo te desengaño, no es por verte, que oirte no querría ni aun olerte (Villalba y Estaña 1886 [1577]: I, 442).

Máis explicitamente vinculadas ao contexto migratorio se amosan as referencias aos galegos e o seu idioma no Diálogo intitulado El Capón, obra escrita por Francisco Narváez de Velilla por volta do ano 1597, e onde o personaxe do Capitán se refería ao "mochachuelo" galego como "el más vozal del mundo", non sen omitir consideracións xenófobas sobre esta figura galega ("Mal haya la casta puta que a Castilla os envió"):

No, este no es sino un mochachuelo que topé en una venta viniendo á Toledo, el mas vozal del mundo, el qual me servia muy bien y habia tres dias que le dí la llave de mi aposento para que me truxera unas cartas, y cogióme una maletilla con algunas cosas de valor y fuéseme [...].

Ea, señor galiçiano, volué el paso atrás hasta llegar á vuestro amo y entregarle eis la maleta, que en Azeca queda. ¡Mal haya la casta puta que á Castilla os envió! (Narváez de Velilla 1916: 286, 307). 
Aplicado decote sobre a diáspora galega, o uso do termo vozal por parte de Narváez de Velilla non está exento dunha carga pexorativa asociada co monolingüismo en galego e a baixa competencia da colectividade galega para falar castelán ${ }^{6}$. Ese sería, precisamente, o significado recollido pola Real Academia Española no seu Diccionario de Autoridades (1726-1739) ao definir o termo vozal como aquel aplicado a "el inculto, y que está por desbastar y pulir" (1726-1729, s.v. vozal) e que -engade a entrada- "ordinariamente se dá à los Negros, en especial quando están recien venidos de sus tierras: y se aplíca tambien à los rústicos”. Deste xeito, e con independencia da súa orixe étnica e/ou nacional, o termo vozal viña a subliñar a condición "rústica", "inculta" —isto é, non asimilado aínda na cultura e lingua do exogrupo receptor dominante-, dun individuo, en tanto que falante dun código lingüístico incomprensíbel, opaco ou "cerrado" desde o punto de vista dos membros do exogrupo receptor. Nesta mesma idea incide Chaudenson, ao lembrar como a etiqueta vozal/bozal resultaba común entre os colonos casteláns/españois para se referiren aos "new slaves who were unable to speak that language comprehensibly" (2002: 88). Tal sería a influencia do elemento lingüístico que o descoñecemento do idioma dos seus amos entre os escravos subsaharianos acabaría por crear unha categoría destes baixo a denominación de "negro bozal", en que se englobaba a todo escravo africano que "se expresaba con dificultad en castellano" (Morales 2004: 442), cando non a aqueles "who were incapable of commicating in the master's language and often incapable of communicating with each other" (Quintero 2016: 98).

A pesar de se situar en condicións sociais diverxentes, como recorda Rey Sánchez, o certo é que tanto "gallegos" como "negros" constituíron dúas das comunidades máis satirizadas pola literatura peninsular durante a Idade Moderna, se ben esa burla estaba ben estendida sobre outros grupos humanos non-casteláns ou castelanófonos, nomeadamente sobre aqueles "grupos más menospreciados de la sociedad [española] de entonces: gallegos, sayagueses, vizcaínos, asturianos, gitanos, negros, franceses, portugueses, italianos e incluso alemanes" (Rey Sánchez 2010: 18). Baixo este prisma, cuxo principal denominador consistía na denigración do Outro, a incipiente representación de "hablas jergales y dialectales" — práctica común no teatro español

6 Véxase a este respecto, o uso do termo vozal/bozal con que as Constituciones del Estudio de Gramática de esta Ciudad de Tuy-estabelecido en 1543- se referían pexorativamente aos mozos galegos en 1729: "Artículo 13. Del modo de hablar en el estudio y en clase en la ciudad de Tuy. Porque regularmente los mozos de este Reino son sumamente bozales, queremos que mientras estudiaren menores se exorten a que hablen el Idioma Castellano, y ellos se empeñen en cumplirlo, pues de otra suerte ni entienden lo que se les habla y esplica, ni después construien con limpieza. Y por lo que mira a la Cáthedra de Maiores, queremos que hablen Latín en las cosas regulares, pues de esta suerte están más expeditos para la Oración y la Composición. Y no lo haciendo así se proceda a un castigo moderado, como palmas, pérdidas de puntos, estar de rodillas, y otras cosas semejantes; y si esto no fuere bastante se procederá a lo mas conducente" (ap. Maure 1996: 104). 
barroco- obedeceu non só a "una función caracterizadora", mais tamén a un ton burlesco que procuraba provocar un "efecto de superioridad en el auditorio" (Huerta Calvo 1983: 40; ap. Buezo 1994: 420) respecto á "nación representada". No entanto, lonxe de conformar un fenómeno lúdico, meramente literario ou artificioso, o desenvolvemento e uso satírico destes "híbridos lingüísticos" -linguas inventadas, atribuídas a "italianos, negros o moros" (Buezo 1993: 83)- non debe, tal e como sinala Canfield acerca da súa presenza na obra de Góngora, "entenderse como una simple imitación de las burlas", senón "como una consciente representación de la realidad social” (2009: I, 214) que reflectía un comportamento etnocéntrico real, profundamente xenófobo cara aos estranxeiros. Unha postura que, a finais do século XVI, xa se enxerga nas prexuizosa reflexión que o castelán Damasio de Frías y Balboa, dedicaba en 1582 á lingua dos habitantes de "las Asturias y Montañas" no seu Diálogo de las Lenguas (ap. Pensado 1999 [1982]: 22):

Acá también en las Asturias y Montañas, ya vos veis las diferencias de sonidos, o más verdaderamente gruñidos, que hay tan diversos unos de otros, y todos de los castellanos, hablando toda esta gente con un gritillo y unos acentos finales qe a nosotros tanto nos enfadan y a ellos tan bien les suenan.

A concepción de Frías y Balboa, porén, non semella responder a un mero criterio teórico, senón a unha actitude social, especialmente hostil fronte a outros idiomas, e amplamente estendida na Castela da Idade Moderna, a xulgar polas impresións que cara a 1599 manifestaba o barón Conrad von Bemelberg na súa xa célebre Carta de un alemán (ap. García Mercadal 1999: II, 655-656):

La primera de las cuales será que en España y particularmente en Castilla los forasteros son muy bien recibidos (con burlas y matracas entiendo), y lo que es peor, no se les da nada de tocar la honra de las personas, que en hora mala lo sean. La segunda, malaventurado de aquel que no entiende su lengua, y poco menos dichoso quien acabadamente no la habla, porque el primero se acostará sin cena, aunque amanecerá sin deuda, y el segundo no hará poco de buscársela, y corriendo de casa en casa para cohecharla (como los pobres limosna) servirá de pasatiempo a los niños en la plaza.

Produto, talvez, das súas experiencias vitais, a mesma intolerancia social contra os estranxeiros denunciada por Conrad von Bemelberg semella terse producido en Castela, con especial virulencia, contra certas minorías étnicas -a maior parte inmigrantes-, tales como galegos, biscaínos, ciganos ou negros. Como colectivos cuxo denominador común era, en diversos graos, a precariedade económica e a estigmatización social en territorio castelán, as vexacións e sátiras sobre estes repousaron, de acordo con Rey Sánchez, na súa fraqueza económica, pois estes "no solamente son pobres, sino que también tienen una competencia lingüística inferior" 
(2010: 18) no idioma da comunidade receptora. No caso do castelán utilizado polos escravos subsaharianos, coñecido despectivamente na Castela moderna como "jerga de negros", "habla de negros" ou "guineo", idioma parodiado decote nos vilancicos casteláns xunto ao galego, este discorre alén dunha xenreira social para se converter nunha arma de escarnio, tal e como sinalou Moreno Navarro ao estudar o tratamento que recibía en Sevilla a antiga "hermandad de los negros", a través dun testemuño do ano 1604 (1997: 85):

la gente de esta ciudad [Sevilla] los está aguardando de propósito para reir y mofar de ella, y dicen "aguardemos la cofradía de los primos para reir", y así sabe este testigo que cuando salen los dichos morenos se hace mucha burla de ellos [...] Mucha gente los está aguardando para silvarles y hacerles otras mofas y escarnios" consistendes* en "hablarles en guineo y afrentandoles", e incluso "picandoles con alfileres, de lo cual se enojan".

Enmarcado nas representacións cómicas da lingua do Outro, a caracterización lingüística do "mochachuelo" galego - "vozal" e recén chegado a Castela como inmigrante- no Diálogo intitulado El Capón de Narváez de Velilla, tamén resulta de especial interese no estudo da consideración do galego no pensamento castelán barroco, pois "está entre los primeros testimonios del gallego como jerga cómica en la literatura áurea remedando, para regocijo de los castellano-hablantes" (Vian Herrero 1994: 99):

Gallego. Non lo queiro façer. Venna el miño amo, que o folgaré de volverseila, que non teño tanta culpa como vos pensades, que un mozo, miño compañeiro, me engañó he me fizo furtar la maleita.

Vel. Y el dinero, ¿qué se hizo, señor galán?, ¿llevóselo la camarada?

Gallego. Non señor, non me falta mais de tres reales que gastamos en un bodegón, e dos que o le di para que traigese unos pasteles e fugíme de él en tanto. E non me osé volver al miño amo.

Porén, lonxe de procurar un realismo lingüístico, o uso deste híbrido lingüístico -unha "mistura lingüística entre galego e castelán" (Ferreiro 1988: 54)- servía, dun xeito análogo ao tratamento que recibían os idiomas doutras minorías étnicas ou nacionais (gregos, vascos, "negros" etc.) presentes na Castela barroca (Vian Herrero 1994: 99), para que o público, nomeadamente centro-sur peninsular, puidese identificar a nacionalidade da figura cómica, causando así a complicidade e a hilaridade entre o público asistente.

Levadas a cabo habitualmente por grupos socialmente dominantes (Liebkind 2010: I, 22), con certeza este tipo de ridiculizacións lingüísticas —adaptadas á produción 
literaria- contra as minorías non-castelanófonas deberon resultar moi frecuentes na sociedade moderna do centro e sur peninsular. Verbo desta práctica aínda se referiría Gonzalo Korreas en dúas glosas paremiolóxicas do seu Vokabulario de rrefranes i frases proverbiales, apuntando que "solemos [os casteláns/españois] korrutamente imitar los lenguaxes de las naziones vezinas” (1627: 208). Prácticas denigrativas lonxincuas que apenas dúas décadas máis tarde, en 1650, admitía o aragonés Joseph de Casanova, non sen as considerar "muy mala costumbre" (ap. Caramés Martínez 1993: 65):

y a este andar (aunque por diferentes caminos), los de Castilla la Vieja, Montañeses y Gallegos usan de otra infinidad de vocablos con tan mal sonido que nos mueve a risa; y sin embargo, es costumbre de la tierra recibida, pero es muy mala costumbre.

Mais se a ridiculización lingüística do Outro foi especialmente incisiva coas comunidades máis marxinadas dun punto de vista socio-económico, as constantes referencias ao galego, así como a súa conversión nunha "de las hablas más caricaturizadas en los géneros del teatro breve" español (Buezo 1993: 83) deixan entrever igualmente a existencia dun xeneralizado clima de desprezo social por esta lingua, extensión do caricaturizado estereotipo do galego - materializado na exitosa figura literaria do "gallego"-, e cuxa presenza se reflicte profusamente na pluma de numerosos escritores áureos españois.

A través da súa consideración como antítese de cultura e cortesía, o galego chega a ser na Castela -e posteriormente na España moderna-, un recurso xocoso, tal e como se aprecia na novela de Vicente Espinel Relaciones de la vida del escudero Marcos de Obregón (1618) cando o escritor andaluz se refire á falta de formación dun crego "que pronunciaba la lengua Latina como Gallego" (1618: ff. 76v-77r). Este xuízo farase aínda máis explícito nas Rimas humanas y divinas del licenciado Tomé de Burguillos (1634), cando Lope de Vega sentencie que "si a las lenguas la ciencia no acompaña, / lo mismo es saber griego que gallego", aludindo deste xeito, en opinión de Caramés Martínez, “ó problema que supón entenderse tanto na culta lingua grega como na galega, tan baixa" (1993: 100). Asociada no pensamento castelán á rusticidade e á falta de cultura, o galego mesmo aparecerá deshumanizado nas panxoliñas centro e sur peninsulares, convertido nunha lingua propia de "bestas" (ap. Buezo 1994: 444):

Toribio. Mío Señor, yo soy un Burro e no entendo de otra lengua, y así (con perdón de bustedes) voy a falar con las Bestias. 
Dentro dunha consideración deshumanizadora e antigalega, destaca a referencia galega que Francisco Santos manifesta en Dia y noche de Madrid, discursos de lo mas notable que en el passa (1663), onde o costumista madrileño exemplifica o clima xenófobo contra os inmigrantes galegos no Madrid de mediados do século XVII, denominando a estes como "monstruos Galicianos", facilmente recoñecíbeis, en calquera caso, por "el habla" (Santos 1663: 275):

Si este çafio Gallego (dixo Onofre) que en el habla he conocido que lo es, se atreue a esto, q̃ harà quien con alguna libertad puede? Assi está todo perdido (replicò Iuanillo) pues apenas entran estos monstruos Galicianos en Madrid, quando para comer, assen de vna esportilla, ò tomando dos cantaros, trasiegan agua, y luego subiendo a mayores, se acomodan a lacayos de vn señor; y apenas lo son, quando se echan baina abierta, y muy tiessos de cola, se la vàn mirando, como a cosa, que nueuamente sale de aquel bulto, y luego no falta vna Domìnga, que hecha ama por la leche, le dà para coleto, con que a pocos escalones, sube al estremo, que este que và a la carcel.

Non sen certa vinculación coas connotacións que o termo vozal se transparentaba en El Capón, o cualificativo - "zafio" e "zafia"- será especialmente recorrente en numerosas obras de Francisco Santos, tales como El vivo y el difunto (1692) ou Periquillo el de las Gallineras ${ }^{7}$ (1668), á hora de acompañar os seus personaxes galegos, reflectindo a imaxe estereotípica castelá dos galegos como xente basta, ruda ou groseira. Mais para alén da alusión á lingua como marcador étnico e/ou identitario, é posíbel que o epíteto "çafio" utilizado por Santos conteña, implicitamente, unha denigrante referencia á competencia lingüística da comunidade galega. Non en van, a primeira acepción que Sebastián de Covarrubias Orozco (1539-1613) recollía para a voz çafio no seu Tesoro de la lengua castellana o española (1611) non era outra que a do "villano que habla su lengua cerrada, que no sabe otra" (1611: fol. 260v). Sen dúbida, a imaxe do "çafio gallego" ou do galego "que habla su lengua cerrada" e "que no sabe otra" remítenos a unha perspectiva nomeadamente castelá verbo do monolingüísmo que practicaba o continxente inmigratorio galego no centro-sur peninsular. Unha perspectiva sociolingüística castelá que, ligada a consideracións xenófobas ("apenas entran estos monstruos Galicianos en Madrid") respecto da diáspora galega, repousaba na asimetría de status socio-económico existente entre unha maioría dominante -castelá-, competente no seu idioma, e unha estigmatizada diáspora galega, monolingüe no seu, mais de escasa competencia no idioma castelán.

7 "Bolviò la vista para vèr à quién avia de responder, y conociò el sugeto, que era vn zafio Gallego, marido de vna Gallinera" (1704 [1668]: 34). 
Compartida por autores como Mariño Paz (1998: 231-235) ou Freixeiro Mato ${ }^{8}$, entre outros, talvez esta tese atope o seu mellor expoñente a comezos do século XVII, na obra Amor, ingenio y mujer, onde con crúa clareza, Antonio Mira de Amescua revele unha especial repugnancia contra o idioma galego por o considerar apenas unha "lengua de aguadores y lacayos" (2010):

Castaño.
Yo he de hablar
en lo que mi Dios quisiere,
y hablaré sin ceremonia
turco, armenio y persïano,
y en cuantas lenguas es llano
la torre oyó [en] Babilonia,
porque los buenos dotores
algo han de saber en griego;
sólo no hablaré gallego
por ser lengua de aguadores
y lacayos.

Desde este punto de vista, o singular desprezo que Mira de Amescua manifesta verbo da lingua galega non semella ser, máis unha vez, a translación dun estereotipo desvirtuado contra un grupo humano - a diáspora galega— demonizado e aborrecido na Castela seiscentista. Un sentimento xenófobo - concretamente galaicófoboque se atopa ben visíbel, entre outros, nas palabras do anónimo autor de El Tordo Vizcayno (ca. 1638), no que este revela un odio ligado ao factor socio-económico dos inmigrantes galegos, considerando o moucho - metáfora do pobo galego- como ave "esclava de las demás [...] afrenta de nuestra especie" (1850: 15), e de cuxa baixa "estimación prediquen las calles de Castilla, á donde barrenderos, lacayos y esportilleros testifican su bajeza inmunda" (1850: 19).

Este sentimento xenófobo non escaparía aos ollos da colectividade galega, tal e como recordaba o autor de El Búho Gallego (ca. 1620) -obra cuxa autoría é atribuía ao Pedro Fernández de Castro, VII conde de Lemos- ao se referir ao "aborrecemento" e "odio" (ap. Pardo de Guevara Valdés 1997: 354) que o reino de Galiza espertaba entre os españois, e que aínda sería referida polo galego Juan del Río y Otero, quen, con motivo das Festas Minervais en Compostela (1697), aludía á prostración social e institucional do galego, gabándose de escribir "na nosa lingua esquecida, / nomais que por ser galega" (Mariño Paz 1998: 237).

8 "E todo isto derivado dunha situación socioeconómica que levaba moitas persoas monolingües en galego e de condición humilde a teren de se deslocar á corte para realizaren os traballos máis desprestixiados, coas consecuentes burlas e escarnios xeneralizados contra elas e contra a súa forma de falar, como reflicte a literatura española dos chamados séculos de ouro (Freixeiro Mato 2014: 123). 


\section{Conclusións}

A hexemonía política acadada pola monarquía castelá no concerto ibérico ao longo do século XIII, tivo como unha das súas consecuencias máis inmediatas o desenvolvemento dun programa ideolóxico orientado a lexitimar o dominio e expansión da propia Castela. Desde época fernandina (1217-1252), mais especialmente desde o reinado de Afonso X (1252-1284), institucionalizouse unha visión nomeadamente castelán-centrista do Estado, en que a promoción do idioma vernáculo de Castela se converteu nun instrumento do poder rexio.

Se ben nos seus inicios, desde mediados do século XIII, esta promoción aínda mantivo unha convivencia de status social co galego(-portugués), o desenvolvemento -e recuperación- dun supremacismo político-lingüístico coa vitoria dos Trastámara (1369) e o pulo definitivo do castelán no mundo prehumanista, afastará o galego definitivamente da esfera do mundo cortesán na antesala do Renacemento. Esta situación acabaría por relegar as variedades non prestixiadas de castelán, e principalmente os idiomas non-casteláns falados na coroa de Castela, a unha marxinación social de que xa se fan eco numerosos intelectuais casteláns no reinado de Xoán II (1406-1454).

O triunfo e difusión destas teses supremacistas - promovidas desde o propio poder rexio castelán-, xunto ao estereotipo negativo que Galiza e os seus habitantes ocupaba no pensamento castelán catrocentista -en tanto que considerada periferia pobre e rústica-, resultaron determinantes na consideración do galego como un idioma alóxeno, incomprensíbel, rudo e bárbaro no imaxino colectivo castelán, espallándose esta idea quer no mundo académico (véxanse referencias como as de Delicado ou Molina), quer entre o vulgo castelán, a través de paremias ("somos gallegos y no nos entendemos").

Porén, se o avance dunha ideoloxía cortesá castelanista suporá desde o século XV un agravamento do menosprezo contra os idiomas non-casteláns da coroa de Castela, no caso galego, as grandes vagas migratorias iniciadas na segunda metade do século XVI tiveron un impacto crucial na consideración social do galego en Castela. A intensidade do fenómeno inmigratorio e as humildes condicións socioeconómicas da diáspora galega en vilas como Madrid, provocaron a aparición de posición xenófobas (galaicófobas) que agravaron o estereotipo antigalego preexistente e que acabaron proxectándose na lingua dos inmigrantes, concibida finalmente como unha "lengua de lacayos", deostada e parodiada aínda en séculos posteriores. 


\section{Referencias bibliográficas}

Anónimo (1870): El Tordo Vizcayno. Contestación al Búho Gallego (Bilbao: Imp. del «Euscalduna»).

Beltrán de Heredia, V. (1966): Bulario de la Universidad de Salamanca (1219-1549), vol. I (Salamanca: Universidad de Salamanca).

Binotti, L. (2000): “«La lengua compañera del imperio». Observaciones sobre el desarrollo de un discurso de colonialismo lingüístico en el Renacimiento español", en Zwartjes, O. (ed.), Las gramáticas misioneras de tradición hispánica (siglos XVIXVII): 259-287 (Amsterdam: Editions Rodopi).

Bizzarri, H. O. (1995): Refranes que dizen las viejas tras el fuego (Kassel: Edition Reichenberger).

Bourhis, R. Y. / Maass, A. (2005): "Linguistic prejudice and stereotypes", en Ammon, U. / Dittmar, N. / Mattheier, K. J. / Trudgill, P. (eds.), Sociolinguistics: An International Handbook of the Science of Language and Society: 1587-1602. (Berlin / New York: Walter De Gruyter).

Buezo, C. (1993): "En torno a la presencia de Celestina en el teatro breve de los siglos XVI y XVII. Edición de Los Gigantones, entremes de Francisco de Castro", Celestinesca, 17, 3: 67-86.

Buezo, C. (1994): "La figura del gallego en los villancicos toledanos de los siglos XVII y XVIII", en Lorenzo, R. (ed.), Actas do XIX Congreso Internacional de Lingüistica e Filoloxía Románicas, IV, 417-447 (A Coruña: Fundación Pedro Barrié de la Maza).

Cabré, L. (2008): “Un lugar de Petrarca, de Ausiàs March (101) a Fernando de Herrera”, en San José Lera, J. / Burguillo López, F. J. / Mier Pérez, L. (coords.), La fractura historiográfica: las investigaciones de Edad Media y Renacimiento desde el Tercer Milenio, 519-531 (Salamanca: Seminario de Estudios Medievales y Renacentistas (SEMYR), Universidad de Salamanca).

Canfield, M. (2009): Literatura Hispanoamericana: Historia y Antología (Milano: Hoepli).

Caramés Martínez, X. (1993): A imaxe de Galicia e os galegos na literatura castelá (Vigo: Galaxia).

Carreira, A. / Cid Martínez, J. A. (eds.) (1990): La vida y hechos de Estebanillo Gonzalez, hombre de buen humor compuesto por el mesmo (Madrid: Cátedra).

Cátedra, P. M. (1990): Los sermones atribuidos a Pedro Marín: Van añadidas algunas noticias sobre la predicación castellana de San Vicente Ferrer (Salamanca: Universidad de Salamanca). 
Chacón Calvar, R. (2015): "Prestixio e desprestixio do galego en alleas terras". Dispoñíbel en http://bouvard.blogaliza.org/2015/02/17/prestixio-e-desprestixio-do-galegoen-alleas-terras [consult. 4.9.2017].

Chaudenson, R. (2002): Creolization of language and culture (London: Routledge).

Coupland, N. / Giles, H. / Coupland, J. (1991): Language, society and the elderly: Discourse, identity and ageing (Oxford: Basil Blackwell).

Covarrubias Orozco, S. de (1611): Tesoro de la Lengua Castellana, o Española (Madrid: por Luis Sanchez, impressor del Rey N. S.).

Delicado, F. (ed.) (1534): Primaleon. Los tres libros del muy esforçado cauallero Primaleon et Polendos su hermano hijos del emperador Palmerin de Oliua (Venecia: Juan Antonio de Nicolini de Sabio).

Deyermond, A. (1985): "Historia universal e ideología nacional en Pablo de Santa María”, en Homenaje a Álvaro Galmés de Fuentes II, 313-324 (Oviedo: Universidad; Madrid: Gredos).

Deyermond, A. (2009): "Written by the Victors: Technique and Ideology in Official Historiography in Verse in Late-Medieval Spain", en Koope, E. (ed.), The Medieval Chronicle VI, 59-89 (Amsterdam / New York: Rodopi).

Ehrensperger, K. (2013): Paul at the Crossroads of Cultures: Theologizing in the Space Between (London: Bloomsbury T\&T Clark).

Espinel, V. (1618): Relaciones de la Vida del escvdero Marco de Obregón (Barcelona: por Geronimo Margarit).

Esteban, J. (2003): Judas!... Hi... de puta! Insultos y animadversión entre españoles (Sevilla: Editorial Renacimiento).

Fernández Gallardo, L. (2002): Alonso de Cartagena (1385-1456). Una biografía politica en la Castilla del siglo XV (Valladolid: Junta de Castilla y León).

Ferreiro, M. (1988 [1982]): "Unha ruptura na literatura galega: os Séculos Escuros”, en A nosa literatura. Unha interpretación para hoxe, 45-64 (A Coruña: A. C. Alexandre Bóveda).

Ferreiro, M. (2001) [1997]: Gramática Histórica Galega. II. Lexicoloxía (Santiago de Compostela: Edicións Laiovento).

Freixeiro Mato, X. R. (2014): "«A lingua tiveran por lingua d'escravos». O autoodio como concepto sociolingüístico”, Estudos de Lingüística Galega, 6, 117-137.

Garber, K. (2008): "De poesía europea: Política, literatura y lengua en Europa durante la historia moderna”, en Romero Tobar, L. (ed.), Literatura y nación: la emergencia de las literaturas nacionales: 31-61 (Zaragoza: Prensas Universitarias de Zaragoza). 
García de Castro, D. (2006): Refranes que dizen los viejos. Seniloquium. Ed. e trad. de F. Cantalapiedra Erostarbe / J. Moreno Uclés (València: Publicacions de la Universitat de València).

García Mercadal, J. (1999): Viajes de extranjeros por España y Portugal. Vol. II. (Valladolid: Junta de Castilla y León).

González Ollé, F (1999): “Orígenes de un tópico lingüístico: alabanza de la lengua cortesana y menosprecio de la lengua aldeana", en Boletín de la Real Academia Española, tomo LXXIX, caderno CCLXXVII, pp. 197-219. Madrid: Imprenta Aguirre.

Gutierrez Cuadrado, J. / Pascual, J. A. (1995): "De como el castellano se convirtió en español", en García Simon, A. (coord.), Historia de una cultura. La singularidad de Castilla, 2, 319-368 (Valladolid: Junta de Castilla y León).

Herrero García, M. (1966 [1928]). Ideas de los españoles del siglo XVII (Madrid: Gredos).

Horozco, S. (2005 [ca. 1550]): Teatro universal de proverbios. Edición, prólogo, índices, glosario de Hosé Luis Alonso Hernández (Salamanca: Universidad de Salamanca).

Isaac, B. (2004): The Invention of racism in classical antiquity (Princeton, New Jersey: Princeton University Press).

Jost, J. T. / Banaji, M. R. (1994): "The role of stereotyping in system-justification and the production of false consciousness", British Journal of Social Psychology, 33 (1), $1-27$.

Kang, O. / Rubin, D. (2014): "Reverse linguistic stereotyping", en Levis, J. / Moyer, A. (eds.), Social dynamics in second language accent, 239-253 (Berlin: DeGruyter Mouton).

Korreas, G. de (1627): Vokabulario de rrefranes i frases proverbiales $i$ otras fórmulas komunes de la lengua kastellana. Biblioteca Nacional de España, Madrid (Mss/4450).

Kristiansen, G. (2003): "How to do things with allophones: Linguistic stereotypes as cognitive reference points in social cognition", en Dirven, R. / Frank, R. / Pütz, M. (eds.), Cognitive models in Language and Thought: Ideologies, Metaphors, and Meanings, 69-120 (Berlin / New York: Mouton de Gruyter).

Laforse, B. (2013): "Fighting the Other. Greeks and Achaemenid Persians", en Campbell, B. / Tritle, L. A. (eds.), The Oxford Handbook of Warfare in the Classical World, 569-587 (Oxford / New York: Oxford University Press).

Lario Ramírez, D. de (2004): Al hilo del tiempo. Controles y poderes de una España imperial (València: Universitat de València).

Lezcano Montalvo, P. (1993): Crítica del lenguaje ordinario (Madrid: Ediciones Libertarias). 
Liebkind, K. (2010): “Social psychology”, en Fishman, J. / García, O. (eds.), Handbook of language and ethnic identity. I. Disciplinary and regional perspectives (Oxford: Oxford University Press).

López Carreira, A. (2005): O reino medieval de Galicia (Vigo: A Nosa Terra).

Machiavelli, N. (2009): The Prince (Alma Books: Richmond, Surrey).

Mariño Paz, R. (1998): Historia da lingua galega (Santiago de Compostela: Sotelo Blanco).

Martínez Rodríguez, E. (1998): “La poblacion en la Galicia de Felipe II”, en El Reino de Galicia en la Monarquía de Felipe II, 441-471 (Santiago de Compostela: Xunta de Galicia).

Mateo Palacios, A. (ed.) (2013): Flor de virtudes (Zaragoza: Prensas de la Universidad de Zaragoza / Huesca: Instituto de Estudio Altoaragoneses / Teruel: Instituto de Estudios Turolenses).

Maure, X. (1996): "Estudio de Gramática en Tui (Testemuño dunha represión lingüística)", A Trabe de Ouro, 27, 99-109 (Santiago de Compostela: Sotelo Blanco).

Mena, J. de (1501): Las trezientas (Toledo: Pedro Hagembach).

Mira de Amescua, A. (2010): Amor, ingenio y mujer... Alicante: Biblioteca Virtual Miguel de Cervantes / Madrid: Biblioteca Nacional. Dispoñíbel en http://www.cervantesvirtual.com/nd/ark:/59851/bmcgb2n3 [consult. 6.9.17].

Mondéjar, J. (1991): Dialectología andaluza. Estudios (Granada: Don Quijote).

Monsalvo Antón, J. M. (2011): "Poder y cultura en la Castilla de Juan II: Ambientes cortesanos, humanismo autoctono y discursos políticos”, en Rodríguez-San Pedro Bezares, L. E. / Polo Rodríguez, J. L. (eds.), Salamanca y su Universidad en el primer Renacimiento: siglo XV, 15-92 (Salamanca: Ediciones Universidad de Salamanca).

Monteagudo, H. (1994): “A crónica galega dos Reinos de León e Castela na historia e historiografía galegas", en Dadson, T. J. / Oakley, R. J. / Odber de Baubeta, P. A. (eds.), New frontiers in Hispanic and Luso-Brazilian Scholarship, 33-56 (New York: The Edwin Mellen Press).

Monteagudo, H. (1999): Historia social da lingua galega: Idioma, sociedade e cultura a traves do tempo (Vigo: Galaxia).

Morales, J. L. (2004): Poesía afroantillana y negrista: Puerto Rico, República Dominicana, Cuba (San Juan, Puerto Rico: Editorial de la Universidad de Puerto Rico).

Moreno Navarro, I. (1997): La antigua Hermandad de los Negros de Sevilla: Etnicidad, poder y sociedad en 600 años de historia (Sevilla: Universidad de Sevilla / Consejería de Cultura de la Junta de Andalucía). 
Narváez de Velilla, F. (1916): “Diálogo intitulado el Capón”, edición de Lucas de Torre, en Revue Hispanique, XXXVII, 234-321.

Niederehe, H. J. (1985): “Alfonso el Sabio y la fisonomía lingüística de la Península Iberica de su epoca", en Carmona, F. / Flores, F. J. (eds.), La lengua y la literatura en tiempos de Alfonso X. Actas del Congreso Internacional. Murcia, 5-10 Marzo 1984, 415-435. (Murcia: Universidad de Murcia).

Nogueira, C. (2001): A memoria da nación. O reino da Gallaecia (Xerais: Vigo).

Núñez de Toledo, H. (1555): Refranes o proverbios en romance (Salamanca: Juan de Canova).

Obeng, S. G. / Adegbija, E. (1999): "Sub-Saharan Africa", en Fishman, Joshua (ed.), Handbook of Language and Ethnic Identity, 353-368 (New York: Oxford University Press).

Pallas, G. (2006): Missión a las Indias por el P.e Gerónymo Pallas [1619]. Ed. de J. J. Hernández Palomo (Madrid: Consejo Superior de Investigaciones Científicas / La Escuela de Estudios Hispanoamericanos / El Colegio de México / Università degli Studi di Torino).

Parchami, A. (2009): Hegemonic Peace and Empire: The Pax Romana, Britannica and Americana. (London / New York: Routledge).

Pardo de Guevara Valdés, E. (1997): Don Pedro Fernández de Castro, VII conde de Lemos (1576-1622). Estudo histórico (Santiago de Compostela: Xunta de Galicia).

Pensado, J. L. (1985): El gallego, Galicia y los gallegos a través de los tiempos (A Coruña: La Voz de Galicia).

Pensado, J. L. (1999 [1982]): "Evaluacion del asturiano entre las lenguas de España", Lletres Asturianes, 1, 28-40 [Reeditado en Estudios Asturianos. Uviéu: Academia de la Llingua Asturiana].

Peres Vigo, Alexandre (2019): “O estereotipo antigalego cincocentista a través da obra paremiolóxica de Hernán Núñez de Toledo «Los Refranes o Proverbios en Romance» (1555)”, en Marques, M. A. / Sánchez Rei, X. M. (eds.): Estudos atuais de linguística galego-portuguesa, 57-87 (Santiago de Compostela: Laiovento).

Pérez Priego, M. A. (1992): "Sobre la composición de la Gramática castellana de Nebrija”, en Bartol Hernández, J. A., García Santos, J. F. / Santiago Guervós, J. de (eds.): Estudios filológicos en homenaje a Eugenio de Bustos Tovar, 764-770 (Salamanca: Ediciones Universidad de Salamanca).

Quintero, M. C. (2016): Gendering the crown in the Spanish Baroque Comedia (London: Routledge).

Real Academia Española (1770): Diccionario de la lengua castellana (Madrid: Joachin Ibarra). 
Rey Sánchez, G. (2010): Lenguas y dialectos hispánicos en los villancicos del siglo de oro. Edición de villancicos españoles del siglo XVII (1621-1700). Tese de doutoramento, Universidad de Salamanca.

Rodríguez, A. (2003): “De rebus Hispaniae frente a la Crónica latina de los reyes de Castilla: virtudes regias y reciprocidad política en Castilla y León en la primera mitad del siglo XIII", Cahiers de Linguistique et de Civilisation Hispaniques Médiévales, 26, 133-149.

Sala Balust, L. (1962): Constituciones, Estatutos y Ceremonias de los Antiguos Colegios Seculares de la Universidad de Salamanca. Edición crítica (Madrid: Consejo Superior de Investigaciones Científicas / Ediciones de la Universidad de Salamanca, 4 vols.).

Santos, F. (1663): Dia, y noche de Madrid, dicursos de los mas notable en él passa (Madrid: Por Pablo de Val).

Santos, F. (1704 [1668]): Periquillo el de las Gallineras (Valencia: A costa de los herederos de Gabriel de Leon).

Ting-Toomey, S. (1999): Communicating Across Cultures (New York: The Guilford Press).

Vian Herrero, A. (1994): “El «Diálogo intitulado el Capón» tras la huella de «Celestina». Una vez más, una cuestion de genero", Celestinesca, 18/2, 75-111.

Viejo Fernández, X. (2016): "El asturiano en el tránsito de la Edad Media a la Moderna (siglos XIV-XVII): entre el retroceso y la toma de conciencia lingüística", en Mariño Paz, R. / Varela Barreiro, X. (eds.), A lingua galega no solpor medieval, 67-94 (Santiago de Compostela: Consello da Cultura Galega).

Villalba y Estaña, B. (1886): El pelegrino curioso y grandezas de España. Ed. de Pascual Gayangos. Tomo I. (Madrid: La Sociedad de Bibliófilos Españoles).

Wright, S. (1998): "Language as a Contributing Factor in Conflicts between States and within States", en Wright, S. (ed.), Language and Conflict: A Neglected Relationship, 43-65 (Clevedon: Multilingual Matters). 